\title{
Aplikasi SMS Gateway Quick Count Pemilu Berbasiskan PHP
}

\author{
Rifqi Abi Karami ${ }^{1}$, Winangsari Pradani ${ }^{2}$ \\ Program Studi Teknik Informatika, Fakultas Sains dan Teknologi, Universitas Al Azhar Indonesia, Jl. \\ Sisingamangaraja, Kompleks Masjid Agung Al Azhar Indonesia, Kebayoran Baru, Jakarta 12110 \\ Penulis untuk Korespondensi/E-mail: rakarami@if.uai.ac.id
}

\begin{abstract}
Abstrak - Manusia pada dasarnya adalah mahkluk sosial, menjalin sebuah komunikasi yang baik menjadi hal penting dan mutlak dalam membangun sebuah ranah dan komunitas sosial yang baik. Manusia juga merupakan makhluk yang berkelompok sehingga didalam tatanan masyarakat dalam sebuah perkumpulan haruslah terdapat seorang pemimpin dalam kelompok tersebut. Adanya seorang pemimpin menjadikan terciptanya struktur dan rangka kehidupan yang jelas sehingga keberlangsungan kehidupan dapat berjalan dengan baik. Perhitungan suara cepat (Quick Count); atau dikenal sebagai tabulasi suara parallel (Parallel Vote Tabulation) merupakan salah satu metode yang berguna untuk memantau pada hari pemungutan suara. Pada dasarnya Quick Count ini adalah sebuah proses pengumpulan informasi oleh relawan melalui pemantauan langsung pada saat pemungutan suara dan penghitungan suara di Tempat Pemungutan Suara (TPS) yang sudah ditentukan. Sehingga Quick Count adalah proses perhitungan hasil suara berdasarkan sampel yang dikirim relawan kepada server pusat di TPS yang sudah ditentukan bukan total hasil tabulasi yang dilakukan resmi oleh Komisi Pemilihan Umum (KPU).
\end{abstract}

Kata Kunci - Quick Count, Komisi Pemilihan Umum, Tempat Pemungutan Suara.

Abstract - Humans are basically social beings, establishing a good communication becomes an important and absolute in building a good domain and social community. Human being is also a group that in the society in a gathering there must be a leader in the group. The existence of a leader makes the creation of structure and order of life is clear so that the survival of life can run well. Quick Count; otherwise known as parallel voting tabulation (Parallel Vote Tabulation) is one useful method to monitor on voting day. Quick Count Basically this is a process of gathering information by volunteers through direct monitoring during voting and counting at polling stations (TPS) that have been determined. So the Quick Count is the process of calculating the result of the vote based on the sample sent by the volunteer to the central server at the specified TPS, not the total tabulation result done by the General Election Commission (KPU).

Keywords - Quick Count, General Election Commission, Polling Stations

\section{PENDAHULUAN}

$\mathrm{M}$ anusia pada dasarnya adalah mahkluk sosial, menjalin sebuah komunikasi yang baik menjadi hal penting dan mutlak dalam membangun sebuah ranah dan komunitas sosial yang baik. Dan manusia juga merupakan makhluk yang berkelompok sehingga didalam tatanan masyarakat dalam sebuah perkumpulan haruslah terdapat seorang pemimpin dalam kelompok tersebut. Dan adanya seorang pemimpin menjadikan terciptanya struktur dan rangka kehidupan yang jelas sehingga keberlangsungan kehidupan dapat berjalan dengan baik. Didalam pelaksanaannya, KPU bertugas untuk menghitung hasil suara yang di ambil dari Tempat Pemilihan Suara (TPS) serta menetapkan pemenang dari para peserta pemilu. Namun karena proses perhitungan suara yang membutuhkan proses yang lama, 
manual dan secara menyeluruh, maka dibuatlah sebuah metode verifikasi hasil pemilu yang dilakukan dengan menghitung presentase pemilu di TPS yang dijadikan sampel, yaitu Quick Count dengan menggunakan piranti SMS Gateway dalam pengriman dan penerima hasil pemilu melalui SMS.

Berdasarkan permasalahan diatas, peneliti akan membuat sistem yang dapat menghitung jumlah preolehan suara yang didapat dari TPS yang dijadikan sampel secara cepat dan menyajikan rekap data perolehan suara secara cepat.

\section{ANALISA DAN METODOLOGI}

Quick Count atau hitung cepat merupakan sebuah metode verifikasi hasil pemilihan umum yang dilakukan dengan menghitung presentase hasil pemilu di tempat pemungutan suara (TPS) yang dijadikan sampel yang memberikan gambaran dan akurasi yang lebih tinggi, karena menghitung hasil pemilu langsung dari TPS target ${ }^{[1]}$.

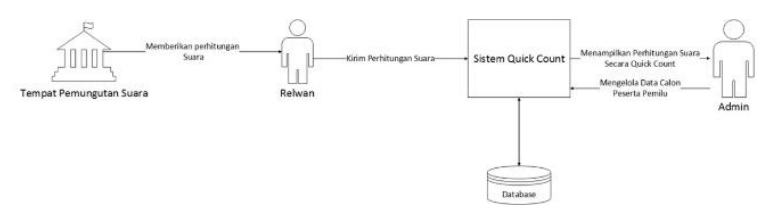

Gambar 1. Proses Bisnis Quick Count

Alur pelaksanaan quick count adalah menentukan jumlah TPS yang akan diamati oleh sistem Quick count. Memilih TPS yang akan diamati secara acak. Management data (pengamatan, pencatatan, dan analisa data hasil perhitungan suara). Lalu terakhir adalah mempublikasikan hasil quick count. Perhitungan pencarian sampel ini ditunjukan untuk mencari jumlah sampel yang akurat serta mengurangi biaya dalam pelaksanaannya. Penghitungan sampel yang biasa digunakan dalam ranah Quick Count adalah rumus Rumus Estok Navitte Cowan ${ }^{[2]}$

$$
\begin{aligned}
& \text { Jumlah Sampel Pemilih } \\
& =\frac{Z^{2}[P(1-P)] \cdot N}{Z^{2}[P(1-P)]+(N-1) \cdot E^{2}}
\end{aligned}
$$

Keterangan :

$\mathrm{Z}=$ Mengacu pada tingkat kepercayaan (untuk $90 \%$ adalah 1.65 , untuk $95 \%$ adalah 1.96 , untuk 99\% adalah 2.58)

$p(1-p)=$ Keragaman populasi dalam bentuk proporsi. Proporsi dibagi dalam dua bagian dengan total $100 \%$. Proporsi yang digunakan adalah pada saat keragaman tertinggi terjadi dimana $p=50 \%$ (atau 0.5).

$E=$ kesalahan sampling yang dikehendaki (sama dengan margin of error)

$N=$ jumlah populasi

Dari Berbagai Lembaga survei yang ada, pada Tahun $2007^{[7]}$ Lingkaran Survei Indonesia (LSI) dan Jaringan Isu Publik (JIP) menggunakan formula untuk menentukan jumlah sampel pemilih dengan menggunakan rumus Estok Navitte Cowan dikarenakan biaya untuk melakukan sampling yang nantinya akan membengkak, dan melihat keragaman pemilih atau pemilih di Indonesia yang tingkat homogennya ${ }^{[3]}$.

Penentuan besaran sampel pada quick count didasarkan oleh derajat keragaman (variability), margin of error (MoE) dan tingkat kepercayaan (confidence interval). ${ }^{[4]}$ Istilah $\mathrm{MoE}$ sering disamaartikan dengan pengertian sampling error (SE), dimana sebenarnya SE dihitung setelah survei selesai dilakukan sesuai dengan teknik sampling yang digunakan. Formula umum menentukan margin of error ${ }^{[2]}$ :

Keterangan:

$$
M o E=\frac{s}{\sqrt{n}} z
$$

$\mathrm{s}=$ simpangan baku (biasanya dianggap 0.5)

$\mathrm{z}=$ nilai $\mathrm{z}$ untuk tingkat kepercayaan tertentu (untuk 90\% adalah 1.96, untuk 99\% adalah 2.58)

$\mathrm{n}=$ ukuran sampel

\section{PERANCANGAN}

Pada sistem ini terdapat dua aktor, yaitu Admin dan Relawan Admin mengelola data calon peserta pemilu dan relawan ke dalam sistem quick count. Sedangkan Relawan mendapatkan hasil perhitungan suara dan dikirimkan ke sistem quick count dengan format sms yang dapat dibaca oleh sistem. Nantinya sistem akan mengolah dan menyimpan data hasil perhitungan suara ke dan dari database. Dan 
akan ditampilkan secara quick count dalam bentuk grafik.

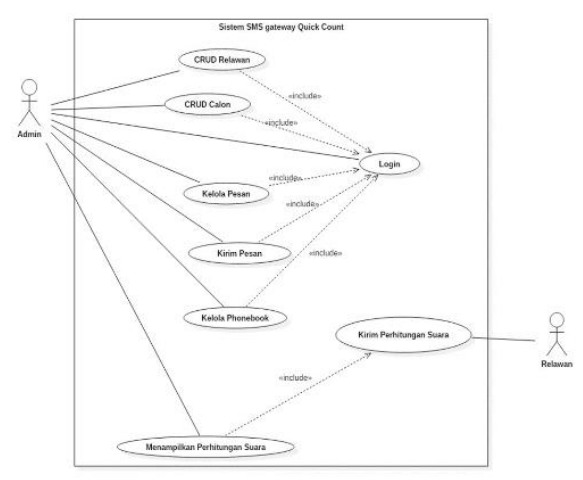

Gambar 2 Use Case Diagram Sms Gateway

Dalam pengiriman hasil suara yang dikirim oleh relawan harus menggunakan format tertentu yang nantinya dikenali oleh sistem dan akan diakumulasikan menjadi total perhitungan suara quick count. Pada kasus ini, format yang digunakan adalah format statis untuk 3 calon peserta pemilu. Dengan format sebagai berikut:

\section{AHY\#NOMOR TPS\#SUARA 1\#SUARA 2\#SUARA 3\#SUARA TIDAK SAH}

Keterangan:

AHY = Singkatan dari salah satu peserta pemilu

Nomor TPS $=$ Nomor urut/nama TPS berdasarkan hasil perhitungan penentuan sampel

Suara $1=$ Jumlah Suara Calon nomor urut 1 (pertama)

Suara 2 Jumlah Suara Calon nomor urut 2 (kedua)

Suara $3=$ Jumlah Suara Calon nomor urut 3 (ketiga)

Suara Tidak Sah $=$ Jumlah suara tidak sah.

Contoh:

\section{AHY\#TPS 212\#100\#80\#150\#14}

Pada contoh diatas artinya, relawan TPS 212 mengirimkan suara untuk calon pertama adalah sebesar 100 suara, calon kedua sebesar 80 suara, calon ketiga sebesar 150 suara dan suara yang tidak sah sebesar 14 suara. Dalam Pengujian sistem Quick Count ini, penulis menggunakan database Data Pemilih Tetap (DPT) yang diambil dari situs kpu.go.id dengan lokasi pada provinsi Banten kota Tangerang
Tabel 1. Daftar Pemilih Tetap di Provinsi Banten Kota Tangerang

\begin{tabular}{|l|r|r|r|r|r|}
\hline \multirow{3}{*}{ Kecamatan } & \multicolumn{5}{|c|}{ Data Pemilih Tetap } \\
\cline { 2 - 6 } & Jumlah & \multicolumn{5}{|c|}{ Jumlah Pemilih } \\
\cline { 3 - 6 } & \multicolumn{1}{|c|}{ TPS } & Laki-laki & Perempuan & \multicolumn{1}{|c|}{ Nihil (\%) } & \multicolumn{1}{c|}{ Total } \\
\hline Batu ceper & 163 & 34.751 & 33.449 & 0 & 68.200 \\
\hline Benda & 135 & 34.078 & 29.852 & 0 & 63.930 \\
\hline Cibodas & 275 & 55.590 & 54.293 & 0 & 109.883 \\
\hline Ciledug & 213 & 46.273 & 45.791 & 0 & 92.064 \\
\hline Cipondoh & 320 & 72.731 & 70.899 & 0 & 143.630 \\
\hline Jatiuwung & 180 & 39.041 & 36.230 & 0 & 75.271 \\
\hline Karang Tengah & 192 & 41.905 & 41.139 & 0 & 83.044 \\
\hline Karawaci & 318 & 63.107 & 62.873 & 0 & 125.980 \\
\hline Larangan & 270 & 52.530 & 51.903 & 0 & 104.433 \\
\hline Neglasari & 180 & 40.100 & 37.745 & 0 & 77.845 \\
\hline Periuk & 210 & 46.350 & 44.940 & 0 & 91.290 \\
\hline Pinang & 259 & 55.729 & 54.654 & 0 & 110.383 \\
\hline Tangerang & 285 & 59.313 & 54.613 & 0 & 113.926 \\
\hline Total & 3000 & 641.498 & 618.381 & 0 & 1.259 .879 \\
\hline
\end{tabular}

Dengan mengacu pada tabel Tabel 1 Daftar Pemilih Tetap di Provinsi Banten Kota Tangerang, jumlah pemilih di kota Tangerang, baik pemilih laki-laki maupun pemilih perempuan, pemilih tetap berjumlah 1.259.879 juta orang jiwa yang dibagi atas 13 kecamatan dan total keseluruhan Tempat Pemilihan Suara (TPS) berjumlah 3000 TPS. Dengan asumsi bahwa Tingkat kepercayaan sebesar 99\%, sampling error $1 \%$ dan tingkat heterogen yang rendahm yaitu $100 \%$, maka dapat dicari jumlah sampel pemilih dengan menggunakan rumus Estok Nattive Cowan dengan perhitungan sebagai berikut:

$$
\begin{aligned}
& \text { Jumlah Sampel Pemilih } \\
& =\frac{Z^{2}[P(1-P)] \cdot N}{Z^{2}[P(1-P)]+(N-1) \cdot E^{2}}
\end{aligned}
$$

\section{Jumlah Sampel Pemilih}

$$
=\frac{(2.58)^{2}[0.1(1-0.1)] \cdot(1,259,879)}{(2.58)^{2}[0.1(1-0.1)]+(1,259,879-1) \cdot(0.01)^{2}}
$$

$$
\text { Jumlah Sampel Pemilih }=5990 \sim
$$

Dari perhitungan diatas, bahwa jumlah sampel pemilih yang akan dipakai sejumlah 5,990 ribu orang di kota Tangerang. setelah itu dilakukan penentuan jumlah sampel Tempat Pemungutan Suara (TPS) dengan melalukan perhitungan dengan menggunakan teknik sampling Systematic Random Sampling. Systematic Random Sampling adalah metode dalam pengambilan sampel dengan melakukan cek keadaan daftar populasi (kerangka populasi) dan menentukan jarak intervalnya. ${ }^{[8]}$ 


$$
\begin{gathered}
\mathrm{t}=\frac{\text { Jumlah Sampel Pemilih }}{\text { rerata pemilih per TPS }} \\
\mathrm{t}=\frac{5990}{1,259,879 / 3000} \\
\mathrm{t}=14 \sim
\end{gathered}
$$

Dari perhitungan diatas, bahwa jumlah sampel TPS yang akan dipakai sejumlah 14 TPS di kota Tangerang. Dalam pemilihan secara acak sampel TPS yang akan digunakan Dari perhitunagan yang dilakukan, dapat dinyatakan dengan

$$
\begin{gathered}
\text { Interval sampel }=\frac{\text { Jumlah TPS keseluruhan }}{\text { Jumlah TPS Sampel }} \\
\text { Interval sampel }=\frac{3000}{14} \\
\text { Interval sampel }=214 \sim
\end{gathered}
$$

Dari perhitungan interval sampel, maka dapat diketahui, jarak interval yang digunakan adalah 1 sampai 214. Setelah itu dipilihlah secara acak sampel pertama dari interval tersebut. Sistem akan memilih secara acak TPS mana yang menjadi sampel TPS pertama yang dipilih dengan menggunakan teknik sampling Sampling Sistematis, yaitu teknik sampling yang menggunakan nomor urut dari populasi baik yang berdasarkan nomor yang ditetapkan sendiri oleh peneliti maupun nomor identitas tertentu, ruang dengan urutan yang seragam atau pertimbangan sistematis lainnya Setelah itu sistem akan memilih secara acak kembali sample TPS selanjutnya hingga jumlah TPS sampel terpenuhi.

\section{KESIMPULAN}

Beberapa simpulan yang diperoleh adalah:

1. Sistem Quick Count dapat membatu mengetahui jumlah suara dengan cepat tanpa menunggu hasil keputusan resmi dari KPU

2. Sistem Quick Count dapat memprediksi hasil penghitungan suara yang dilakukan tanpa menunggu hasil keputusan resmi dari KPU

3. Penggunaan Rumus Estok Navitte Cowan menggunakan sampel yang lebih sedikit dibandingkan dengan menggunakan rumus Slovin

\section{DAFTAR PUSTAKA}

[1] Indra. 2013. Aplikasi Quick Count Untuk Pilkada Dengan Metode Systematic Random Sampling Berbasis Sms

[2] Estok M, Nevitte N \& Cowan G. 2002. The Quick Count and Election Observation. Washington: NDI

[3] Menentukan Sampel untuk Quick Count Pilpres(n.d).http://aswandi.or.id/2014/07/1 3/menentukan-sampel-untuk-quick-countpilpres/. (Diakses pada 24 Desember 2015)

[4] Kismiantini. 2007. Pengumpulan Data Dengan Quick Count Dan Exit Poll. 